\title{
Service Oriented Strategies Applicable for Online Food Suppling Applications with Respect to Users
}

\author{
C. Archanapriya, W. Porselvi, Sumathy Arjunan
}

\begin{abstract}
The current status and situation shows the growth in use of internet and mobile phones. Increasing use of mobile phones and internet leads to digital acting like online shopping, mobile payment, smart marketers use this opportunity and developed many new applications to serve the online customers. In food industry food delivery apps makes huge impact in the online services. This study shows the service strategies used by food delivery apps. The structured questionnaire was used as research tool for understanding the impact on customers. Data was collected from 50 respondents in south Chennai. Anova and descriptive analysis was used to analyze the responses. The main aim of the study was to analyze the service strategies and its impact on customers. Also to find out the most preferred food delivery app in southern Chennai and the factors influencing the use of food delivery apps.
\end{abstract}

Keywords : Food delivery apps, business methods, online service

\section{INTRODUCTION}

Customers' response to the online application creates opportunities for many businesses. The development of online shopping and online payment encourage people to use these applications[1]-[3]. Food delivery apps meet the needs of busy people who place their online order and delivery within a few minutes.

Online nourishment requesting is the nourishment conveyance or take-out process through a website page or application from a nearby café or nourishment agreeable. A considerable lot of these administrations, including purchasing purchaser products on the web, expect clients to keep accounts with them to make continuous shopping simple. The rapid growth and usage of food delivery apps creates a very competitive battle ground in the digital economy[4]-[7]. In south chennai best food delivery apps like zomato, swiggy provides a wide service to their customers. To meet the wide the wide customers needs and service in the competitive market the online food delivery service provider adopts different service strategies to attract customers. serivces like free door delivery, rewards, GPRS tracking,

Revised Manuscript Received on December 11, 2019.

C. Archanapriya, Department of Science and Humanities, Bharath Institute of Higher Education and Research, Chennai, India. Email: Archanapriya854@gmail.com

W. Porselvi, Department of Science and Humanities, Bharath Institute of Higher Education and Research, Chennai , India. Email: porselviwilson@gmail.com

Sumathy Arjunan, Department of Science and Humanities, Bharath Institute of Higher Education and Research, Chennai, India. Email: sumi.renu@gmail.com and advance booking influences the customer to use these applications.

\section{REVIEW OF LITERATURE}

1.Lee, E., Lee, S., \& Jeon, Y. (2017). The apparent convenience was essentially influenced by client produced data, firm-created data, and framework quality. Furthermore, the perceived ease of use was strongly influenced by system quality and design quality.

2.Riley Panko( 2018 ) Many factors, such as the variety of restaurant options, discounts, and apps, affect how smartphone owners make the most of their favorite food delivery app.

3.Luzmary villegas (2016) The online prescence will be crucial for the future growth of your app and it will also help you grow the businesses you will work with.I suggest you to list your app in the different websites that are dedicated to promote new apps, in addition you could get your own website in which you could provide detailed information about the way it performs, its advantages, etc.

4.Hemant (2017) When you think of a food delivery app business, you need to target two clients. One is the restaurant and the other the user. Every different food application tries to target different type of audience. Before investing into a mobile app development you need to ensure you have all the elements intact that compromise of features that make a reliable food delivery app.

\section{A. Objective}

1.To find out the most preferred food delivery app in south chennai.

2. To evaluate the food delivery Apps ' product approaches and their effect on customers.

\section{B. Hypothesis}

1. Ho- There is no noteworthy connection among age and effect of food delivery apps on customers.

H1- There is no noteworthy connection among age and effect of food delivery Apps on customers.

\section{RESEARCH METHODOLOGY}

1.Research configuration is an itemized research study configuration venture.

The examination utilized engaging exploration plan. 
2.Descriptive research endeavors to clarify the wonder in a deliberate way and gives information on frames of mind and desires to the inquiry.

3Sampling procedure is the gathering of a subset of individuals from a tremendous populace to evaluate the qualities of the southern chennai 50 respondents. For this examination, the straightforward irregular strategy was picked.

4. Straightforward irregular testing strategy accept that every single unit in the populace has equivalent possibility or probability of event and the inspecting units are haphazardly chosen. The scientist haphazardly took 50 examples from the general populace. Essential wellsprings of information gathered from magazines, diaries and sites through polls in google structures and auxiliary source[8]-[14].

\section{RESULTS AND DISCUSSIONS}

\section{A. Hypothesis test 2}

Ho- There is no noteworthy connection among age and effect of food delivery apps on customers.

H1- There is no noteworthy connection among age and effect of food delivery Apps on customers

\begin{tabular}{|l|l|l|l|l|l|}
\hline & $\mathrm{N}$ & $\begin{array}{l}\text { Minimu } \\
\mathrm{m}\end{array}$ & $\begin{array}{l}\text { Maximu } \\
\mathrm{m}\end{array}$ & Mean & $\begin{array}{l}\text { Std. } \\
\text { Deviation }\end{array}$ \\
\hline $\begin{array}{l}\text { most preferred food } \\
\text { deliver apps (swiggy) } \\
\text { most preferred food } \\
\text { deliver app (zomato) } \\
\text { most preferred food } \\
\text { deliver app (ubereats) }\end{array}$ & 50 & 1 & 5 & 4.60 & .782 \\
$\begin{array}{l}\text { most preferred food } \\
\text { deliver app( food } \\
\text { panda) }\end{array}$ & 50 & 1 & 5 & 4.16 & 1.037 \\
$\begin{array}{l}\text { most preferred food } \\
\text { deliver app( faasos) } \\
\text { Valid N (listwise) }\end{array}$ & 50 & 1 & 5 & 3.92 & 1.158 \\
\hline
\end{tabular}

Table 1 : Most preferred food delivery app

The above table shows the mean rank values of the different food delivery apps. Swiggy is the most preferred app having high mean value 4.60 and get first rank. Zomato get 2 nd rank, ubereats get 4 th rank andfinaly faasos get 5 th $\operatorname{rank}[15]-[18]$.

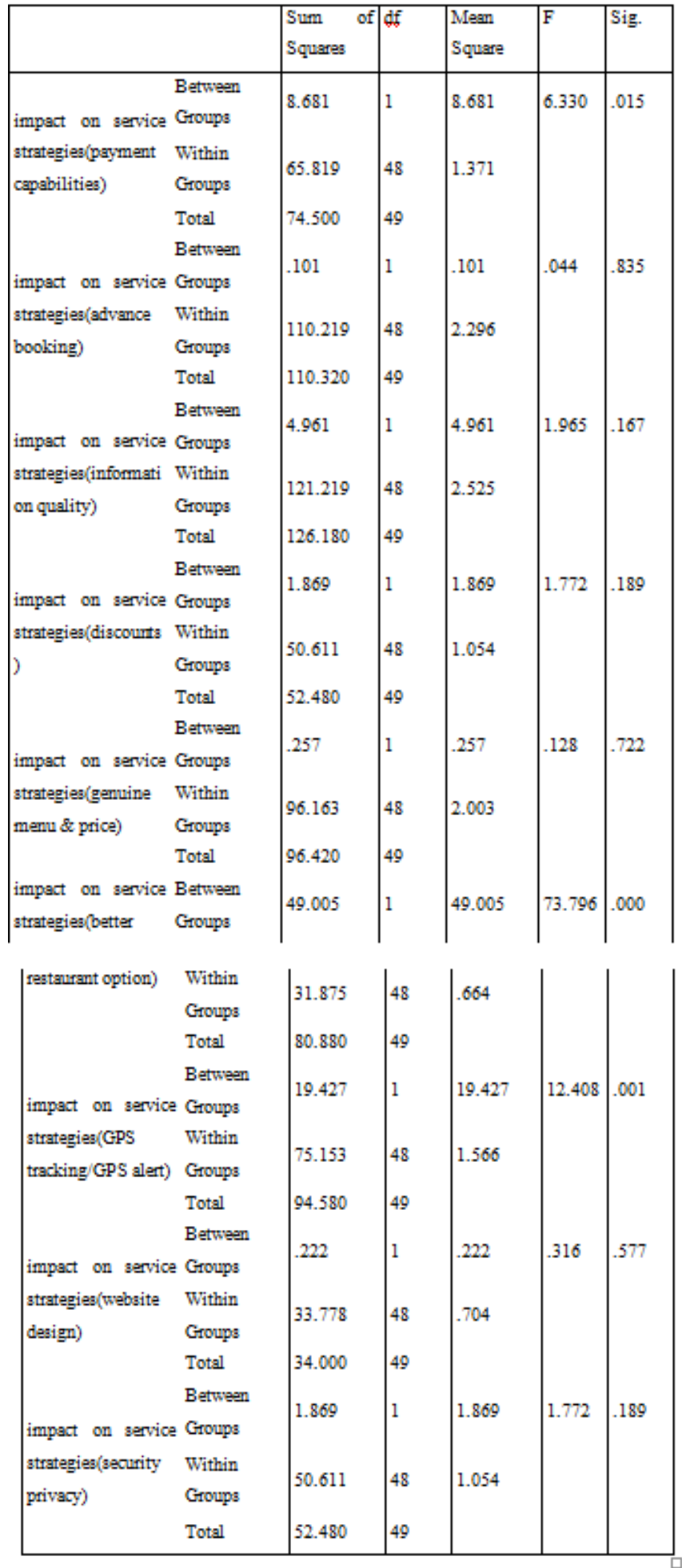

Table 2: ANOVA Table

Table reveals that $41 \%$ of sample respondents who have joined in SHG belongs to category of earning less that Rs. 1,000 per month. $90 \%$ of women who have joined SHG belong to a family whose income are less than Rs. 3000. This shows that lower income female members are more interested to join SHG as they provide alternative employment opportunities to enhance their family income. 


\section{FINDINGS}

Out of 50 respondents 17 assenters are below 20 years, 22 assenters are between the age group 21-30, 7 respondents are between the age group 31-40 and only 4 respondents are above 40 years[19]-[22].

Out Of 50 assenter, 32 assenter are male and 18 respondents are female.

Greater part of the assenter fall under the income group Rs.15000-Rs. 25000

Factors like discounts, fast delivery, easy to use, variety of food having the significant value as less as 0.05 .so the alternative hypothesis is accepted

Strategies like payment capabilities, better restaurant option, GPS tracking/GPS alert having the significant value as less as $0.05[23]-[25]$.

\section{CONCLUSION}

Attempts were made in this analysis to classify the service strategies and their impact on customers towards food delivery apps. Results suggest that online food delivery apps makes a great impact on online service and customer perception towards online food ordering. Factors like convenience, easy to use mostly influence the customers to prefer these apps and the services like offers and discounts, GPS tracking makes the customers to use these apps. The aftereffects of this investigation offer help for the positive relationship between the service strategies adopted by the food delivery apps and their impact on customers.

\section{REFERENCES}

1. Vasanthi, S. \& Rabiyathul Basariya, S. 2019, "Influence of value analysis and cross training in industry", International Journal of Engineering and Advanced Technology, vol. 8, no. 6, pp. 1810-1811.

2. Velvizhi, R., Sri Gowtham, S. \& Jeya Priya, D. 2019, "Examination of early feedbacks for effective product retailing on E-commerce websites", International Journal of Engineering and Advanced Technology, vol. 8, no. 6 Special Issue 2, pp. 703-706.

3. Anuradha, C., Pothumani, S. \& Kavitha, R. 2019, "A novel method towards E-commerce", International Journal of Engineering and Advanced Technology, vol. 8, no. 6 Special Issue 2, pp. 535-538.

4. Thomas, J. \& Rabiyathul Basariya, S. 2019, "A study on the issues of financial ratio analysis", Indian Journal of Public Health Research and Development, vol. 10, no. 3, pp. 1079-1081.

5. Ramachandran, S. \& Rabiyathul Basariya, S. 2019, "Online marketing study on customer satisfaction and relationship", Indian Journal of Public Health Research and Development, vol. 10, no. 3, pp. 1072-1078.

6. Priya, R., Vinothini, G. \& Cor Jesu, C.D. 2019, "The mentor-protégé relationship for professional growth", Journal of Advanced Research in Dynamical and Control Systems, vol. 11, no. 9 Special Issue, pp. 1110-1119.

7. Jannifer Rani, N., Bina Pani, S. \& Nimisha, N.S. 2019, "A study on money back polices available in LIC", Journal of Advanced Research in Dynamical and Control Systems, vol. 11, no. 9 Special Issue, pp. 833-839.

8. Saillaja, V., Jhansi Rani, K. \& Catherine, R. 2019, "Global marketing management planning and organization", Journal of Advanced Research in Dynamical and Control Systems, vol. 11, no. 9 Special Issue, pp. 489-493.

9. Saillaja, V., Jhansi Rani, K. \& Catherine, R. 2019, "The new phase of marketing information system", Journal of Advanced Research in Dynamical and Control Systems, vol. 11, no. 9 Special Issue, pp. 482-488.

10. Thoufiqulla \& Raju, D.V. 2019, "Perception of indian investor towards investment in mutual funds with special reference to mip funds", Journal of Advanced Research in Dynamical and Control Systems, vol. 11, no. 5, pp. 177-183.
11. Jasmine, K.R.M. \& Basariya, S.R. 2018, "A study on the customer benefits on mutual funds", International Journal of Civil Engineering and Technology, vol. 9, no. 4, pp. 45-48

12. Vasanthi, S. \& Basariya, S.R. 2019, "Pros and cons of on the job training versus off the job training", International Journal of Scientific and Technology Research, vol. 8, no. 10, pp. 671-674.

13. Pavithra, J. \& Ganesan, M. 2016, "A study on awareness and impact of micro-financial schemes", International Journal of Applied Business and Economic Research, vol. 14, no. 8, pp. 5449-5460.

14. Pavithra, J., Dilli Babu, P. \& Ambuli, T.V. 2014, "A study on budgetary control at Maruti Service Masters, Chennai", International Journal of Applied Business and Economic Research, vol. 12, no. 2, pp. 151-161.

15. Gunaraja, T.M. \& Venkatrama Raju, D. 2018, "Determining factors of organisational climate with reference to leadership styles", International Journal of Mechanical Engineering and Technology, vol. 9, no. 9, pp. 1327-1332.

16. Gunaraja, T.M. \& Venkatrama Raju, D. 2018, "The role of job satisfaction and training of employees in determining organisational climate of a selected industry", International Journal of Civil Engineering and Technology, vol. 9, no. 8, pp. 1266-1269.

17. Aarathy, T.S. \& Raju, D.V. 2018, "Performance appraisal and its effects on employees with respect to it sector in Chennai city", International Journal of Civil Engineering and Technology, vol. 9, no. 6, pp. 1535-1538.

18. Aarathy, T.S. \& Raju, D.V. 2018, "Employee perception towards performance appraisal system in IT sector", International Journal of Mechanical Engineering and Technology, vol. 9, no. 5, pp. 131-135.

19. Porselvi, W., Jublee, D. \& Sivanesan, G. 2018, "A study on factors influencing adoption of technology and innovation in banking industry, tamilnadu, India", International Journal of Mechanical Engineering and Technology, vol. 9, no. 5, pp. 789-800.

20. Akessa, G.M. and Dhufera, A.G., 2015. Factors That Influences Students Academic Performance: A Case of Rift Valley University, Jimma, Ethiopia. Journal of Education and Practice, 6(22), pp.55-63.

21. Miller, G. and Shih, C.C., 1999. A faculty assessment of the academic rigor of on-and off-campus courses in agriculture. Journal of Agricultural Education, 40, pp.57-65.

22. Tsinidou, M., Gerogiannis, V. and Fitsilis, P., 2010. Evaluation of the factors that determine quality in higher education: an empirical study. Quality Assurance in education, 18(3), pp.227-244.

23. Farooq, M.S., Chaudhry, A.H., Shafiq, M. and Berhanu, G., 2011 Factors affecting students' quality of academic performance: a case of secondary school level. Journal of quality and technology management, 7(2), pp.1-14

24. Fitsilis, P., Gerogiannis, V. and Anthopoulos, L., 2014. Ontologies for software project management: a review. Journal of Software Engineering and Applications, 7(13), p.1096.

25. Adams, J.D. and Jaffe, A.B., 1996. Bounding the effects of R\&D: an investigation using matched establishment-firm data(No. w5544). National bureau of economic research.

\section{AUTHORS PROFILE}

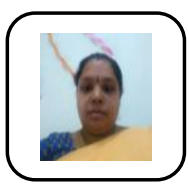

C. Archanapriya Assistant Professor, Department of Science and Humanities, Bharath Institute of Higher Education and Research, Chennai , India.

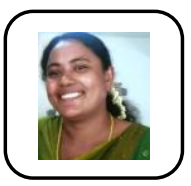

W. Porselvi Assistant Professor, Department of Science and Humanities, Bharath Institute of Higher Education and Research, Chennai, India.

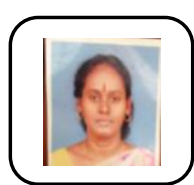

Sumathy Arjunan Assistant Professor, Department of Science and Humanities, Bharath Institute of Higher Education and Research, Chennai, India. 